Frey, Bruno S.; Steuernagel, Armin; Friedrich, Jonas

\title{
Working Paper \\ Future European Alliance - Europe as a Flexible Democracy
}

CESifo Working Paper, No. 7270

\section{Provided in Cooperation with:}

Ifo Institute - Leibniz Institute for Economic Research at the University of Munich

Suggested Citation: Frey, Bruno S.; Steuernagel, Armin; Friedrich, Jonas (2018) : Future European Alliance - Europe as a Flexible Democracy, CESifo Working Paper, No. 7270, Center for Economic Studies and ifo Institute (CESifo), Munich

This Version is available at:

http://hdl.handle.net/10419/185468

Standard-Nutzungsbedingungen:

Die Dokumente auf EconStor dürfen zu eigenen wissenschaftlichen Zwecken und zum Privatgebrauch gespeichert und kopiert werden.

Sie dürfen die Dokumente nicht für öffentliche oder kommerzielle Zwecke vervielfältigen, öffentlich ausstellen, öffentlich zugänglich machen, vertreiben oder anderweitig nutzen.

Sofern die Verfasser die Dokumente unter Open-Content-Lizenzen (insbesondere CC-Lizenzen) zur Verfügung gestellt haben sollten, gelten abweichend von diesen Nutzungsbedingungen die in der dort genannten Lizenz gewährten Nutzungsrechte.
Terms of use:

Documents in EconStor may be saved and copied for your personal and scholarly purposes.

You are not to copy documents for public or commercial purposes, to exhibit the documents publicly, to make them publicly available on the internet, or to distribute or otherwise use the documents in public.

If the documents have been made available under an Open Content Licence (especially Creative Commons Licences), you may exercise further usage rights as specified in the indicated licence. 


\section{CEsifo \\ WORKING

\section{Future European Alliance}

\section{Europe as a \\ Flexible Democracy}

Bruno S. Frey, Armin Steuernagel, Jonas Friedrich 


\section{Impressum:}

CESifo Working Papers

ISSN 2364-1428 (electronic version)

Publisher and distributor: Munich Society for the Promotion of Economic Research - CESifo $\mathrm{GmbH}$

The international platform of Ludwigs-Maximilians University's Center for Economic Studies and the ifo Institute

Poschingerstr. 5, 81679 Munich, Germany

Telephone +49 (o)89 2180-2740, Telefax +49 (o)89 2180-17845, email office@cesifo.de

Editors: Clemens Fuest, Oliver Falck, Jasmin Gröschl

www.cesifo-group.org/wp

An electronic version of the paper may be downloaded

- from the SSRN website: $\quad$ www.SSRN.com

- from the RePEc website: $\quad$ www.RePEc.org

- from the CESifo website: www.CESifo-group.org/wp 


\title{
Future European Alliance Europe as a Flexible Democracy
}

\begin{abstract}
A reasonable future for Europe can only be achieved if two essential elements are fulfilled: Firstly, newly established institutions must be democratic and have strong support from citizens rather than from national governments. Secondly, the large number of different ethnic, cultural, religious, and regional units existing on the European continent must be able to maintain their identity. This diversity must be institutionally supported rather than be undermined by standardization and centralization. We suggest political institutions, which are formed to meet these goals, following the example of Functional, Overlapping, Competing Jurisdictions (FOCJ). If these two goals are adequately reached, a future alliance raises the identification with the European project, and induces citizens to exhibit civic virtue in strengthening these goals.
\end{abstract}

JEL-Codes: H100, H400, K330, P400, P480, R100.

Keywords: Europe, flexible institutions, identity, diversity, FOCJ, European Union.

\author{
Bruno S. Frey* \\ University Basel, CREMA \\ Zurich / Switzerland \\ bruno.fey@bsfrey.ch
}

\author{
Armin Steuernagel \\ CREMA \\ Zurich / Switzerland \\ armin.steuernagel@bsfrey.ch
}

\author{
Jonas Friedrich \\ CREMA \\ Zurich / Switzerland \\ jonas.friedrich@bsfrey.ch
}




\section{Towards a Democratic and Diverse Europe}

The requirements of democratic, flexible political institutions caring for diversity can be reached by restructuring Europe according to political issues and problems to be solved, rather than according to historically (and often accidentally) composed national units. New jurisdictions with taxing power are to be formed by citizens, communes, regions, and only in a few cases also by nations. These new political units must be democratic; the citizens must be able to have a strong say on how the problems are taken up and solved (possibly via popular initiatives and referenda) ${ }^{1}$. They experience that issues relevant to them are indeed taken up by politicians and the public administration, that their preferences are taken into account or that they can organize themselves to handle political issues by their own. In turn, the possibility to address problems and strong democratic participation rights will activate citizens, create identification and a sense of belonging. In particular, they can form jurisdictions focusing on, and strengthening their various local, regional, or cultural identities. A Flexible Democracy seems to us the most adequate answer for the set up for a future European Alliance.

\section{The European Union of Nation States}

Despite the fact that European units have existed for 60 years, first in the form of the European Coal and Steal Community, then the European Economic Community and finally the European Union, citizens' identification and trust has been rather weak. Despite the small recent increases in trust levels, overall trust has decreased over time.

One of the longest time series concerning the identification and trust in European institutions provided by the European Statistical Office (Eurostat) is “Trust in the European Commission”" (see Figure 1). As may well be seen, the share of European citizens having trust in the European Commission drops considerably from $53 \%$ to $46 \%$ between 1993 and 2018, i.e. by seven percentage points. In contrast, the share of citizens not having trust has increased from $25 \%$ to $39 \%$, i.e. by fourteen percentage points.

\footnotetext{
${ }^{1}$ This is the concept of FOCJ - Functional, Overlapping, Competing Jurisdictions, as developed in the book by Frey and Eichenberger (1999), as well as in a number of earlier articles by Frey (e.g. 1996). Our contribution does not describe and expound the idea yet another time but deals with new issues confronted by the existing unification attempts within the European Union (see e.g. the president of the EU-Commission Junker and the French president Macron).
} 
Figure 1: Trust in the European Commission (1993-2018)

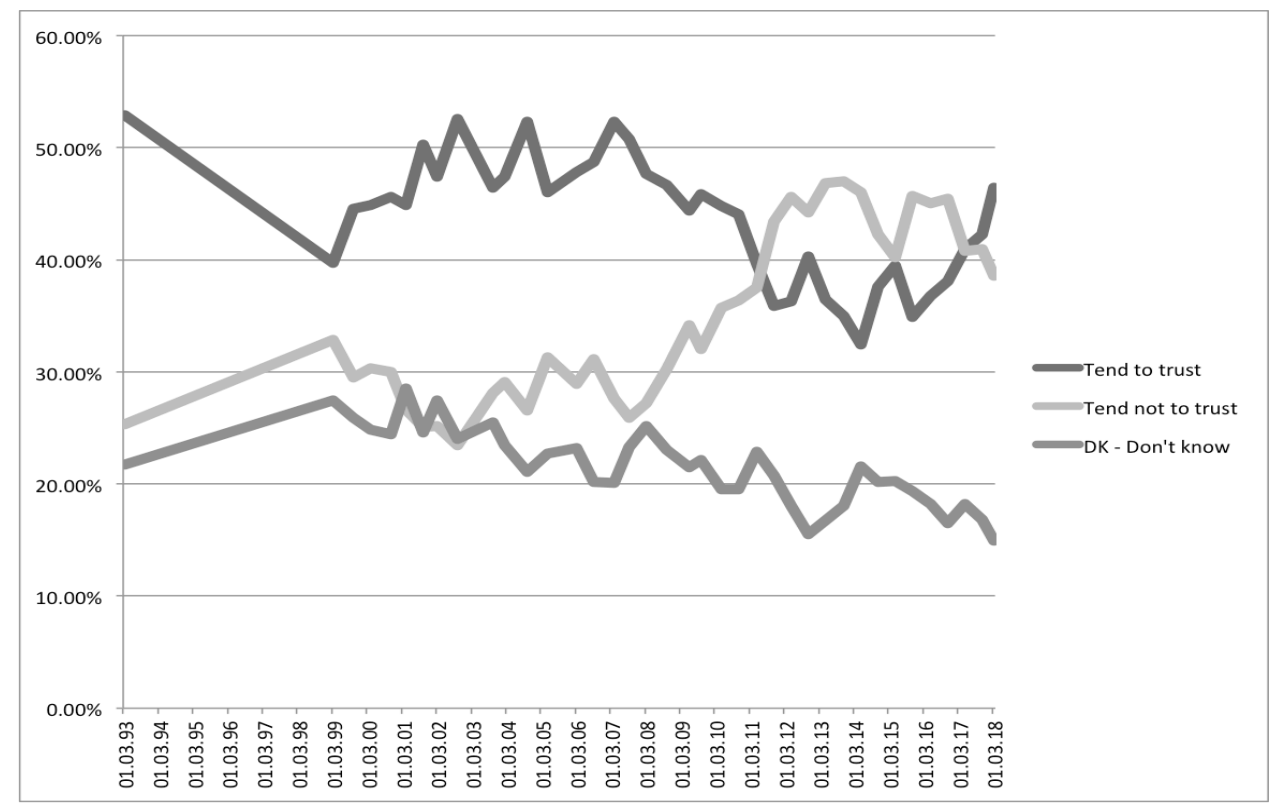

Source: Eurobarometer 2018

A similar development holds for the European Parliament: trust in the European Parliament by European citizens dropped from $54 \%$ in 1993 to $50 \%$ in 2018, i.e. by four percentage points; and the share of European Citizens not trusting the European Parliament increased from $24 \%$ to 39 \%, i.e. by fifteen percentage points.

Figure 2: Trust in the European Parliament (1993-2018)

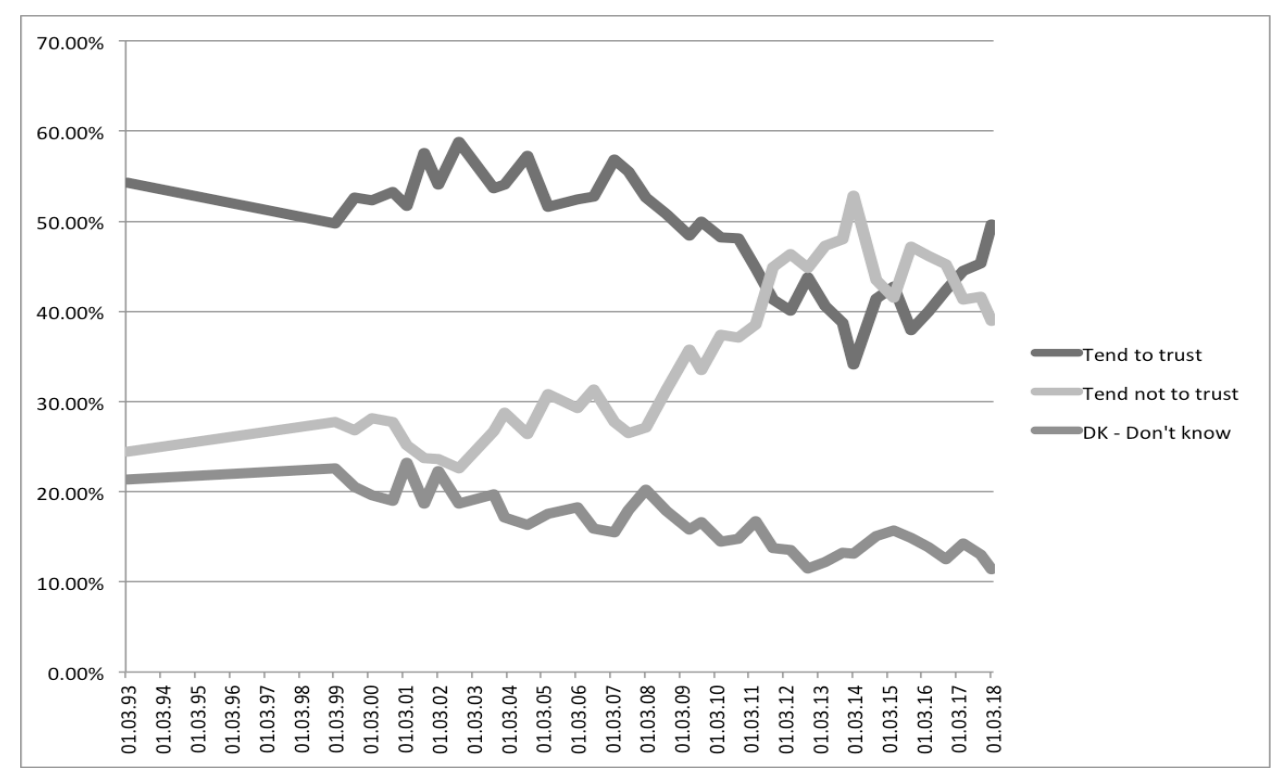

Source: Eurobarometer 2018 
Time series data for trust in the European Union, Central Bank, European Commission and the European Parliament combined is, however, only available starting form 2005. Figure 3 displays a significant drop in trust for all four major EU institutions.

Figure 3: Trust in major European Institutions

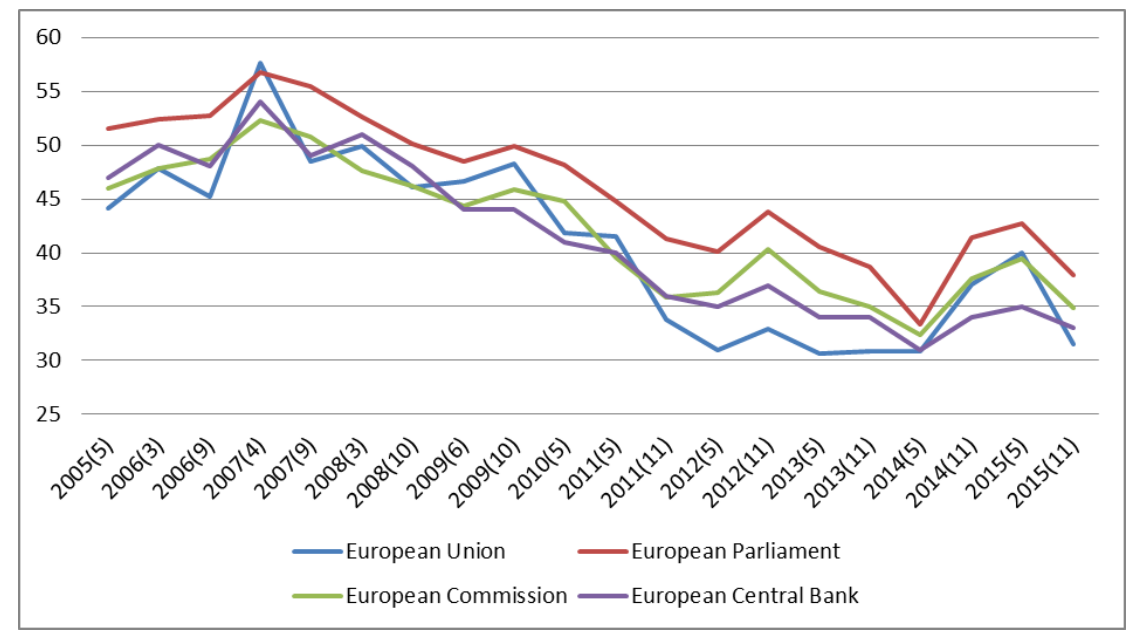

Source:

Consortium of Trust Research - Pathways to Political Trust (CONTRE), 2015

Besides the reported trust in European institutions, a large survey undertaken in 2016 on identification of citizens with territories can inform our analysis. According to “Generation What?”, European citizens identify little with Europe and significantly more with their own city and region, with their own country (nation) and with the world as a whole. Table 1 reveals the respective figures for Europe as a whole, Germany, France and Italy.

Table 1: $\quad$ Do you feel you are most acutely part of ...?

\begin{tabular}{|l|c|c|c|c|c|} 
& $\begin{array}{c}\text {...own city and } \\
\text { region }\end{array}$ & .. own country & ...Europe & .. World & $\begin{array}{c}\text { Number } \\
\text { surveyed }\end{array}$ \\
\hline Germany & $38 \%$ & $24 \%$ & $12 \%$ & $26 \%$ & 122000 \\
\hline France & $27 \%$ & $32 \%$ & $8 \%$ & $32 \%$ & 60000 \\
\hline Italy & $28 \%$ & $26 \%$ & $13 \%$ & $33 \%$ & 81000 \\
\hline Europe (all) & $32 \%$ & $32 \%$ & $11 \%$ & $26 \%$ & 504000 \\
\hline
\end{tabular}

Source: “Generation What?”, Abschlussbericht 2016

The empirical data presented above show both low trust in European institutions and low identification with Europe. We assume that these findings are strongly related to the political regime existing in the European Union. National governments as main operators in the politics of the EU are at the core of the problem; they are neither helpful to support identification with Europe nor to create trust in EU institutions. Many scholars have pointed out how the mainly inter-governmental structure of decision 
making in the EU is confronted with a "democracy deficit" (e.g. Follesdal and Hix 2006. Citizens have little potential to become politically involved, while the competences of Brussels institution are step by step further enlarged.

From the very beginning, European unification has been based on nations as the acting units. There are only weak attempts to consider other actors such as regions. Their influence on the course of the European project is minute, most importantly as the European regions have no relevant taxing power. This means that their activities are dictated from the EU politicians and administration in Brussels.

As long as the European project was mainly focused on establishing free trade, the role of nations was of little importance because free trade means that the national borders with respect to the mobility of goods, services, capital and labor are overcome. The situation became quite different when the goal switched to political unification. Nations were the dominant, and only actors. Indeed, solely relying on national entities to advance the European project has been met with serious problems. We claim that the politico-institutional structure of the EU tends to crowd out identification and trust, due to deficient democratic participation rights and centralized structures. Empirical studies have shown that higher democratic participation rights increase identification, social capital, and civic virtues ${ }^{2}$; citizens feel recognized, heard and taken seriously (Frey, Stutzer and Benz 2001). The "democracy deficit" in the EU creates adverse conditions. Furthermore, Europe is a colorful continent with a multitude of cultures, ethnicities, religions, languages and customs, which cannot be represented in a centralized political structure.

We therefore conclude that it is unwarranted to push the European project solely by nations, intergovernmentalism and a weak European Parliament. Rather, nations should increasingly lose importance, making way for a more flexible democratic regime, which allows for a decentralized organization of political issues. To rely on "Country Clubs", which are set up between different nations, has serious limits in both respects: they are likely to be little democratic, and they undermine the desire for diversity and plurality as essential elements of Europe.

\section{New European Actors}

The issue and problem-orientated jurisdictions suggested by us - we call them Functional, Overlapping, Competing, Jurisdictions (FOCJ) (Frey and Eichenberger 1995, 1999) - rely on a multitude of actors and certainly are not confined to nations. We suggest that citizens are given the possibility to address public issues from below and may establish new jurisdictions catering to these problems. The same applies to communes, regional units and in very limited cases countries. What actor is best suited depends on many conditions, the most important being the territorial extension of a

\footnotetext{
${ }^{2}$ For further research on the effects of stronger democratic participation on civic virtues and trust see Frey (1997).
} 
given issue $e^{3}$. Thus, it is very much in the European spirit if communes on opposite sides of a national frontier establish a jurisdiction in order to deal with issues with which they are directly confronted (e.g. management of a river or lake). No higher level political unit, such as Bundesländer or provinces, and in particular national states or the European Union itself should have the right to interfere or block these co-operations.

The new functionally orientated jurisdictions can be introduced step by step by enabling flexible democratic structures firstly in only a few fields and keeping the old institutions as fallback ${ }^{4}$ options (Eichenberger and Frey 2006). The institutional design must guarantee that actors below nations are ably to establish jurisdictions catering to specific problems, say schooling, roads, water, electricity, noise abatement or security.

\section{Possible Counterarguments}

The new jurisdictions proposed here are quite unconventional and therefore likely to be considered impossible to achieve, or undesirable compared to the present political situation, including country clubs.

Four problems should be seriously considered:

(1) It may be argued that the establishment of problem-orientated jurisdictions is complicated, especially as there will be a large number of them.

This argument may be directed to citizens each of whom will be a member of various such new jurisdictions. This is in sharp contrast to today's situation in which citizens vote for parliamentary representatives who decide about all issues. However, with respect to the new jurisdictions, the citizens find it much easier to inform themselves, and to take a decision because each one is dealing with one issue only (say, whether to build a bridge or to fund a theatre). This corresponds to the situation in direct democracies where the citizens are able to decide about specific issues of content. Moreover, parties and interest groups will also supply information and advise the citizens how to decide. The citizens also find it easier to monitor and control the politicians, as their activity is restricted to one particular area so that the scope of responsibility is well established.

The argument of increased complexity may also affect politicians. However, their task tends to become less complicated because the unbundling of tasks allows them to concentrate on one particular issue. Experts may help them in the specific areas. Experts are persons who are

\footnotetext{
${ }^{3}$ The idea draws on the classical principles of fiscal equivalence by Olson (1969). And furthermore draws on the Decentralization Theorem by Oates (1972).

${ }^{4}$ For further explanation see section Vl.
} 
knowledgeable in one particular field (say water supply), and whose advice is necessary and welcome.

It may be argued that the task becomes much more difficult for the public administration which has to cope with a large number of new jurisdictions. This argument is not convincing because each jurisdiction will have a staff of its own well versed in the particular area.

Moreover, as the new jurisdictions are based on formal contracts, new digital technologies, like block-chain technology, may help to overcome the problems created by the larger number of jurisdictions.

(2) It may be thought that the unbundling of the public sector according to functions undermines the sense of belonging, or people's identity. There is no longer one political entity encompassing all political aspects. This argument is not convincing because citizens may establish jurisdictions especially catering for aspects of identity (or "Heimat") providing, for example, education in traditional crafts, specific cultural events, etc. This is another area where there need not necessarily be a public institution, which tends to create standardized solutions, but where specific societies are able to provide diverse offers. In contrast to the existing regime, Flexible Democracy allows people to create institutions matching their identity.

(3) The unbundling or splitting up of political functions into separate jurisdictions may be claimed to disregard the interdependencies between the various functions. This is certainly an important issue to be considered. The various political areas must link up with each other in a reasonable way. Thus, for instance, public transport must be adapted to the organization of education, in particular that pupils and students can easily reach the location of the schools.

This problem exists also today. There is no administration covering all functions in the same unit; it would be far too large to be efficient. To take up the previous example, the school administration is a quite separate unit from the traffic authority. Already today, interdependencies must be solved by negotiating between the public units. If no agreement is reached, there must be mechanisms to overcome the conflicts. This may be undertaken by a third party with a meta-perspective. The same holds for the jurisdictions organized along functional jurisdictions. It must be admitted that the negotiations may be more cumbersome because the jurisdictions organized along functions are more independent than individual departments in a traditional public administration. This can be considered a disadvantage of the new kind of jurisdictions. There is indeed a trade-off. The functionally organized jurisdictions are better able to take into account the preferences of the citizens, and are more efficient in putting them into action because the citizens are able to control them more tightly. This advantage must be weighted against the possibly higher cost of dealing with the interdependencies between areas. 
(4) Citizens may free ride in the case of public goods. A case in point is an educational jurisdiction formed by citizens without children. They are able to reduce the tax rate to nil, as they have no expenditures to carry. In that case there must be a superior rule determining that, say, the average tax for schools must be raised and distributed to the other jurisdictions actually providing education.

In some cases a different, and more efficient solution may be possible. Take the case of an opera house to be financed by a local community. For this purpose, a specific jurisdiction may be formed which raises the necessary taxes. All opera house visitors not belonging to the respective jurisdiction must pay a full price covering all costs they produce. In contrast, the members of the jurisdiction running the opera house get a (large) discount.

\section{Historical Experiences}

The issue-orientated jurisdictions here proposed may at first sight appear to be outlandish, and impossible to institute in a future Europe. But such a view overlooks the fact that democratic singleissue jurisdictions with taxing power exist in variations today and have historical precursors.

For example the political system of Switzerland is characterized by a great variety of different political institutions and strong direct democratic participations rights in all three levels of jurisdiction (Linder 2017). In addition to 26 cantons, the small country with roughly 8 million citizens organizes political issues in approximately 8000 communes (Frey 1997). The most important of these are political communes (2940), which are similar to traditional federal political units with defined territorial extension and a fixed bundle of political tasks. Nevertheless, political communes possess significant autonomy and levy their own taxes, which vary substantially between communes. Furthermore, various forms of direct democratic participation institutions exist. However, in addition to these traditional forms of communes, there are several thousand further political jurisdictions, which deal with specific political tasks. There are citizen communes (1519), school communes (516), church communes (2555), corporations (309), fractions (78) and civil communes (73) (ibid). Several of them are task specific and most of them display a different territorial expansion then political communes and cantons.

Furthermore, in Switzerland there exits a rising number of associations of communes (Zweck- und Gemeindeverbände), which solve specific public tasks like sewage systems, hospitals and nursing homes in the territorial expansion that are taken to be economically efficient.

A number of studies shows that this distinct and highly diversified form of federalism as well as strong direct democratic participation reduces government expenditure and increases performance (e.g. Feld and Schaltegger 2017) ${ }^{5}$.

\footnotetext{
${ }^{5}$ The authors investigate in their comprehensive work the economic, political and societal performance of the Swiss competitive federalism. They find that the highly decentralized federalist structure tends to
} 
In the United States of America about 39,000 special districts organize mostly specific political functions. The most common fields are natural resources, fire protection, water supply, housing, sewerage, cemeteries, libraries, parks and recreation, highways, hospitals, airports, electric power or gas supply, or public transit (Hooghe and Marks 2003). These jurisdictions are created by legislative action, court decision or public referendum. The formation and supervision however lies on some level of government and must conform state law. Rights to taxation can in some cases be delegated to the special district administration. The overall number of special districts rose in the last 65 years threefold from 12,340 in 1952 to approximately 39,000 today (ibid). In contrast to the Swiss communes, the special purpose districts often lack democratic accountability and have a reputation of being a tool to establish undemocratic coalitions among politicians and public officials.

Another example of decentralized political organization is the concept of National Cultural Autonomy ${ }^{6}$. The concept seeks to reduce ethnic conflict in modern democracies by allowing different ethnicities living in one society to set up their own jurisdictions for their cultural issues. Citizens can unite and set up their own cultural political body and within it organize their own schools and cultural activities (Nimni 2004). In Estonia between 1925 and 1940, the Law for National Cultural Autonomy was the first to introduce this concept. It paved the way for the German and the Jewish minority to organize schools and culture specific activities in their own political jurisdictions ${ }^{7}$. In the case of National Cultural Autonomy the political jurisdictions are overlapping; anywhere in Estonia, citizens could freely decide whether they wanted to be part of German, the Jewish or the general Estonian "nation". Thus, task specific jurisdictions existed side by side on the same territory and enabled to protect minority rights and a culturally diverse society.

Another example can be provided by German cooperatives. These cooperatives have set up their own regulatory framework, enforce it with their own coop-oversight associations and constantly further develop their contents. This is the reason why the state-driven financial oversight authorities in Germany (Bafin) refrain from overseeing the coops' activities, although they do financial investments: the law that is putting many restrictions on normal companies when they take on small investors, is not relevant for coops. Only in the case when coop-oversight associations are not able to prevent scandals, the Bafin will get active. Furthermore, it is practice that coop-supervisors notify the Bafin if they observe infringements by their members.

\section{Step-wise introduction of Flexible Democratic Units}

have a positive influence on economic performance, public debt, the quality of public services, innovation, technical efficiency, social capital and tax morale (Feld et al. 2017, 292 et seq.).

${ }^{6}$ For the first conceptualization of the political concept see Renner (1899)

${ }^{7}$ The concept of National Cultural Autonomy was partly implemented in several post-soviet states without significant success. However, scholars argue that the deficiencies are mainly to be attributed to incomplete legal introduction of the concept. See Nimni (2007). 
The current political regime in the EU is highly complex and the relationships between various political actors are sophisticated. Therefore, a full blown reshuffling of the political system in the direction of a Flexible Democracy does not seem reasonable. However, flexible and issue-based political entities that provide public service or even provide alternative regulation can very well be introduced step-wise and bottom up. But what happens if citizens or other actors try to establish a flexible political unit (or FOCJ) that deals with issues that the EU or nation state has already dealt with? In this case the bottom-up entity should have the right to prove over a certain period that it can do the task of regulation or public service provision as good as the original national or EU solution. Only if it proofs to not work the „old“ still exiting regulations and mechanisms would kick in as fallback law. One could imagine a growing number of non-profit banks and investment funds that focus on creating a positive social and environmental impact (impact investing) would want to opt-out of the tight bank regulations that have been created for profit-seeking banks. Instead they could propose an own regulatory framework, which better suits their purposes and is more flexible. It would be not country specific but industry-, region-, or task-specific. In these cases the EU should grant a fifth freedom: the freedom of political association and self-management. This freedom would also enable different solutions that can achieve the original aim of a EU regulation, but uses other means. As long as the actors that propose new entities for public services or regulation can show that they are not producing more harm but that they can control the potential malicious behaviors of actors much more effectively than the EU-wide one-size fits all regulation, they should be left free to choose their own ways. Only if it can be proven that they cannot prevent harm, the EU-wide regulation would kick in as „fallback“ law.

FOCJ add an innovative concept of public good provision and regulation that would respect the diversity of Europe and allow solving problems that the EU and nation states currently try to solve by central regulation.

\section{Conclusions}

Flexible Democracy proposed here fulfills the requirements for a multi-speed and multi-tier regime in an extreme way. Multi-speed is fulfilled because every actor - may it be individuals, communes, regions, and countries - can decide at what moment of time to set up, enter and possibly exit a newly emerging jurisdiction devoted to a particular problem or area. Our proposal is an extreme fulfillment of a multi-tier institutional setting, as the political activity is organized according to functions in various individual political bodies. The multi-tier setting here favored, however, is explicitly not confined to nations as actors, i.e. we do not advocate "country clubs". Mere cooperation between nations, which we face in the current political regimen in the EU, does not serve for bottom up cooperation and a diverse Europe. We propose a Flexible Democracy consisting of a multitude of differently sized political institutions, which may serve best in establishing a future alliance for Europe. It is especially emphasized, that trust and identification with politics can be fostered through strong democratic participation rights and is therefore a core element in the proposed bouquet of political entities. 
Furthermore, a more decentralized and flexible set up of the European political system rather keeps and strengthens the diversity of Europe, than narrowing it down through central institutions. It allows for flexible and selective cooperation.

The proposal also discusses four major objections to the concept of Flexible Democracy and the political diversification, and provides first counter arguments. Furthermore, historical examples of flexible and decentralized democratic institutions are depicted. Finally, an introduction scenario of a Flexible Democracy for Europe is investigated, which relies on the idea of gradual introduction through fallback laws.

The development of the European integration manifesting in the EEC and later in the EU shows that a future Europe composed of nations does not fulfill the essential goals of citizens participation and does not bring to fruit the immense cultural, political and social diversity defining Europe. Our concept of a Flexible Democracy for Europa is designed to meet these requirements.

\section{Bibliography:}

Eichenberger, R. and B. S. Frey (2006). "Functional, Overlapping and Competing Jurisdictions (FOCJ): A Complement and Alternative to Today's Federalism." In: E. Ahmad and G. Brosio (eds.), Handbook of Fiscal Federalism, Edward Elgar, Cheltenham, UK and Northampton, MA, USA: 154181.

Feld, L. P., C. A. Schaltegger, H. Burret and L. Schmid (2017). Föderalimus und Wettbewerbsfähigkeit in der Schweiz, NZZ libro, Verlag Neue Zürcher Zeitung.

Follesdal, A. and S. Hix (2006). "Why There is a Democratic Deficit in the EU: A Response to Majone and Moravcsik." JCMS: Journal of Common Market Studies 44(3): 533-562.

Frey, B. S. (1996). "A Directly Democratic and Federal Europe." Constitutional Political Economy 7(4): 267-279.

Frey, B. S. (1997). "A Constitution for Knaves Crowds Out Civic Virtues." Economic Journal 107(443): 1043-1053.

Frey, B. S. and R. Eichenberger (1995). Competition Among Jurisdictions: The Idea of FOCJ. In: L. Gerken (ed.) Competition among institutions, Palgrave Macmillan, London: 209-229.

Frey, B. S. and R. Eichenberger (1999). The New Democratic Federalism for Europe. Edward Elgar: Cheltenham UK and Northhampton MA, USA. 
Frey, B. S., A. Stutzer and M. Benz (2001). Trusting Constitutions. Économie publique/Public Economics, 7(1): 25-41.

Hooghe, L. and G. Marks (2003). Unraveling the Central State, but How? Types of Multi-level Governance. American Political Science Review 97(02): 233-243.

Linder, W. (2017). Schweizerische Demokratie. Haupt Verlag: Bern.

Nimni, E. (ed.) (2004). National Cultural Autonomy and its Contemporary Critics, Routledge: London and New York.

Nimni, E. (2007). National-Cultural Autonomy as an Alternative to Minority Territorial Nationalism. Ethnopolitics 6(3): 345-364.

Oates, W. E. (1972). Fiscal Federalism. Harcourt Brace Jovanovich: New York.

Olson, M. (1969). The Principle of 'Fiscal Equivalence': the Division of Responsibilities Among Different Levels of Government. American Economic Review 59(2): 479-487.

Renner, K. (1899). Staat und Nation. Zur Österreichischen Nationalitätenfrage, Dietl: Wien.

\section{Tables and Figures:}

Figure 1: Eurobarometer 2018;

http://ec.europa.eu/commfrontoffice/publicopinion/index.cfm/Chart/getChart/chartType/gridChart//the $\underline{\text { meKy/9/groupKy/23/savFile/661 }}$

Figure 2: Eurobarometer 2018;

http:/ec.europa.eu/commfrontoffice/publicopinion/index.cfm/Chart/getChart/chartType/gridChart//the $\underline{\text { meKy/9/groupKy/23/savFile/661 }}$

Figure 3: Consortium of Trust Research - Pathways to Political Trust (CONTRE):

http://blogs.uta.fi/contre/2016/02/11/trust-in-the-eu-short-term-fluctuations-or-a-more-long-term-trend/

Table 1: "Generation What? Abschlussbericht" 2016:

http://www.generation-what.de/portrait/data/europe 